\title{
Molten Salt Destruction of Base. Hydrolysate
}

\author{
Bruce E. Watkins \\ Ronald L. Kanna \\ Ronald D. Chambers \\ Ravindra S. Upadhye \\ César O. Pruneda \\ Energetic Materials Center \\ Lawrence Livermore National Laboratory
}

This paper was prepared for submittal to

Lt. Scott R. Jeffers, Project Officer

United States Air Force

Eglin, Florida

October 1996

This is an informal report intended primarily for internal or limited external distribution. The opinions and conchusions stated are those of the author and may or may not be those of the Laboratory.

Work performed under the auspices of the U.S. Department of Energy by the Lawrence Livermore National Laboratory under Contract W-7405-ENG-48. 


\section{DISCLAIMER}

This document was prepared as an account of work sponsored by an agency of the United States Government. Neither the United States Government nor the University of California nor any of their employees, makes any warranty, express or implied, or assumes any legal liability or responsibility for the accuracy, completeness, or usefulness of any information, apparatus, product, or process disclosed, or represents that its use would not infringe privately owned rights. Reference herein to any specific commercial product, process, or service by trade name, trademark, manufacturer, or otherwise, does not necessarily constitute or imply its endorsement, recommendation, or favoring by the United States Government or the University of California. The views and opinions of authors expressed herein do not necessarily state or reflect those of the United States Government or the University of California, and shall not be used for advertising or product endorsement purposes.

This report has been reproduced directly from the best available copy.

Available to DOE and DOE contractors from the Office of Scientific and Technical Information

P.O. Box 62, Oak Ridge, TN 37831

Prices available from (615) 576-8401, FTS 626-8401

Available to the public from the

National Technical Information Service

U.S. Department of Commerce

5285 Port Royal Rd.,

Springfield, VA 22161 


\section{Introduction}

As a result of the end of the Cold War and the shift in emphasis to a smaller stockpile, many munitions are scheduled for rapid dismantlement and demilitarization. Major components of these munitions are the explosives and propellants, or energetic materials. The DoD has several hundred million pounds of energetic materials in its demilitarization inventory, with millions more added each year. Although recycling and reusing is the preferred method of dealing with these surplus materials, there will always be the necessity of destroying intractable or unusable energetic materials. Traditionally, open burn/open detonation (OB/OD) has been the method of choice for the destruction of energetic materials. Public concerns and increasingly stringent environmental regulations have made open burning and open detonation of energetic materials increasingly costly and several states have banned OB/OD. Thus, the impetus to develop environmentally sound alternatives to dispose of energetic materials is great.

We have previously demonstrated the Molten Salt Destruction (MSD) Process for the destruction of $\mathrm{HE}$ and HE-containing wastes. MSD converts the organic constituents of the waste into non-hazardous substances such as carbon dioxide, nitrogen and water. Any inorganic constituents of the waste, such as binders and metallic particles, are retained in the molten salt. The destruction of energetic material waste is accomplished by introducing it, together with air, into a crucible containing a molten salt, a suitable mixture of sodium, potassium, lithium carbonates.

In addition to MSD other processes have been proposed to destroy energetic material waste. Each of these processes is unique and each is optimally effective for a different subset of the demilitarization inventory. Each of these processes produces solid, liquid and gaseous waste streams. Base hydrolysis is a demilitarization process that renders explosive materials non-reactive. This may be a cost effective process to demilitarize a fraction of the demil inventory, particularly for decontaminating large metal parts (bomb casings). The base hydrolysis process produces a hazardous liquid waste stream. This report describes experimental results of the destruction of base hydrolysate from four explosives (Tritonal, Octol, Comp B3, and PBXN-109) by molten salt. 


\section{Experimental}

The Los Alamos National Laboratory (LANL) has investigated the use of base hydrolysis for the demilitarization of explosives. Cary B. Skidmore from LANL provided LLNL with the following samples:

$\begin{array}{ll}\text { Comp B hydrolysate } & \text { 3 liters } \\ \text { Octol hydrolysate } & \text { 3 liters } \\ \text { Tritonal hydrolysate } & 4 \text { liters } \\ \text { PBXN-109 hydrolysate } & 4 \text { liters }\end{array}$

Appendix 1 describes how these samples were prepared. No data were provided for the Comp B experiments. Chemical analyses of the hydrolysate were not provided.

The hydrolysate was processed in the 7 foot tall pilot molten salt unit located in building 191 at the LLNL main site. An insulated downcomer $(3.75$ inches $\mathrm{OD} / 1$ inch ID) was used that ran from the top to within 6 inches of the bottom of the vessel. A 3/8 inch OD coaxial feed tube was contained within the downcomer that ran to within 4 inches of the bottom of the downcomer. The hydrolysate was pumped through the inner tube and air was delivered down the main downcomer. We found that is important to use this type of downcomer assembly to prevent evaporation of liquid and deposition of solid material in feed streams with a high loading of dissolved solids.

The hydrolysate was processed at 82 gram per minute into a carbonate salt bath at 735 to $770^{\circ} \mathrm{C}$. Oxygen in the exhaust ran at 12 to $16 \%$ due to the low concentration of reduced carbon in the feed liquid. NOx and carbon monoxide emissions were low and are presented in Table 1. No other emissions, other than carbon dioxide were measured.

Table 1. Emissions from the molten salt destruction of base hydrolysate

Explosive

Tritonal

Octol

PBXN-109

Comp B-3
NOx (ppm)

51

52

30

18
CO (ppm)

40

140

2777

152

\section{Results and Discussion}

The processing of these base hydrolysate solutions proceeded in a straightforward manner without notable occurrences. The emissions from these materials were quite low with one exception. The generally low emissions 
were due to the low concentration of dissolved organic and NOx generating inorganic components (such as nitrate/nitrite) in the solution.

In one case (PBXN-109) the emissions of carbon monoxide was quite high (2777 ppm). This material was hydrolyzed using 20 to 50\% DMSO to swell the binder. This was necessary since the binder used in PBXN-109 is not hydrolyzed by sodium hydroxide and a limited reaction occurred in aqueous solutions. The resulting hydrolysate contained substantial quantities of DMSO, which does not burn cleanly at the operating temperature used to destroy explosives $\left(750^{\circ} \mathrm{C}\right)$. The amounts of carbon monoxide could be reduced by .operating the molten salt unit at higher temperatures (e.g. $900^{\circ} \mathrm{C}$ ).

These experiments processed base hydrolysate at 1.4 gallons per hour, and the time required to process the liquid from all four explosives required 3.5 hours. This was insufficient time to reach steady state. The feed material was not completely characterized, so any conclusions drawn from these experiments must be considered as preliminary. However, 14 liters of material was processed is a short amount of time without incident. With one exception (noted above) the gaseous emissions from the molten salt destruction of base hydrolysate were low. We are, therefore, hopeful that molten salt destruction is an ideal method to process waste from a largescale base hydrolysis program.

Appendix 1. Preparation of base hydrolysate

(Provided by Cary B. Skidmore of Los Alamos National Laboratory) 


\section{Experimental Summary for the DOD Explosives: Base Hydrolysate was a mixture of all the experiments using the same explosive}

\section{Effectiveness of base hydrolysis on Octol:}

\begin{tabular}{|l|l|l|l|l|l|l|l|l}
\hline $\begin{array}{l}\text { Experiment } \\
\#\end{array}$ & $\begin{array}{l}\text { Mass of } \\
\text { Explosive }\end{array}$ & Description & $\begin{array}{l}\text { Concentration } \\
\text { of Base }\end{array}$ & $\begin{array}{l}\text { Volume } \\
\text { of Base }\end{array}$ & $\begin{array}{l}\text { Peak } \\
\text { Temp. }\end{array}$ & $\begin{array}{l}\text { Time at } \\
\text { Temp. }\end{array}$ & $\begin{array}{l}\% \\
\text { reacted }\end{array}$ & Date \\
\hline $\mathrm{CSX}-46^{\circ}$ & $16.935 \mathrm{~g}$ & Scrap & $1.5 \mathrm{M} \mathrm{NaOH}$ & $200 \mathrm{~mL}$ & $93^{\circ} \mathrm{C}$ or $>$ & 106 minutes & 99.7 & $2 / 15 / 96$ \\
\hline $\mathrm{CSX}-47^{*}$ & $23.831 \mathrm{~g}$ & 1 piece & $3 \mathrm{M} \mathrm{NaOH}$ & $200 \mathrm{~mL}$ & $80^{\circ} \mathrm{C}$ or $>$ & 30 minutes & 99.8 & $2 / 20 / 96$ \\
\hline $\mathrm{CSX}-58^{5}$ & $105.55 \mathrm{~g}$ & 2 cylinders & $3 \mathrm{M} \mathrm{NaOH}$ & $1000 \mathrm{~mL}$ & $150^{\circ} \mathrm{C}$ & $\begin{array}{l}\sim 1 \\
\text { minute** }\end{array}$ & 99.0 & $2 / 26 / 96$ \\
\hline $\mathrm{CSX}-59$ & $181.51 \mathrm{~g}$ & 2 cylinders & $3 \mathrm{M} \mathrm{NaOH}$ & $1000 \mathrm{~mL}$ & $80^{\circ} \mathrm{C}$ or $>$ & 28 minutes & 94.6 & $2 / 27 / 96$ \\
\hline
\end{tabular}

* A Solid salt of TNT is formed in the ammonia experiment, so the determination of how much Octol was reacted is difficult to determine.

** Due to a rapid exotherm (see temperature profile for CSX-58) the time at temperature was not accurately determined.

s Stirring was used.

Temperature and pressure profiles for the Octol experiments

CSX-46

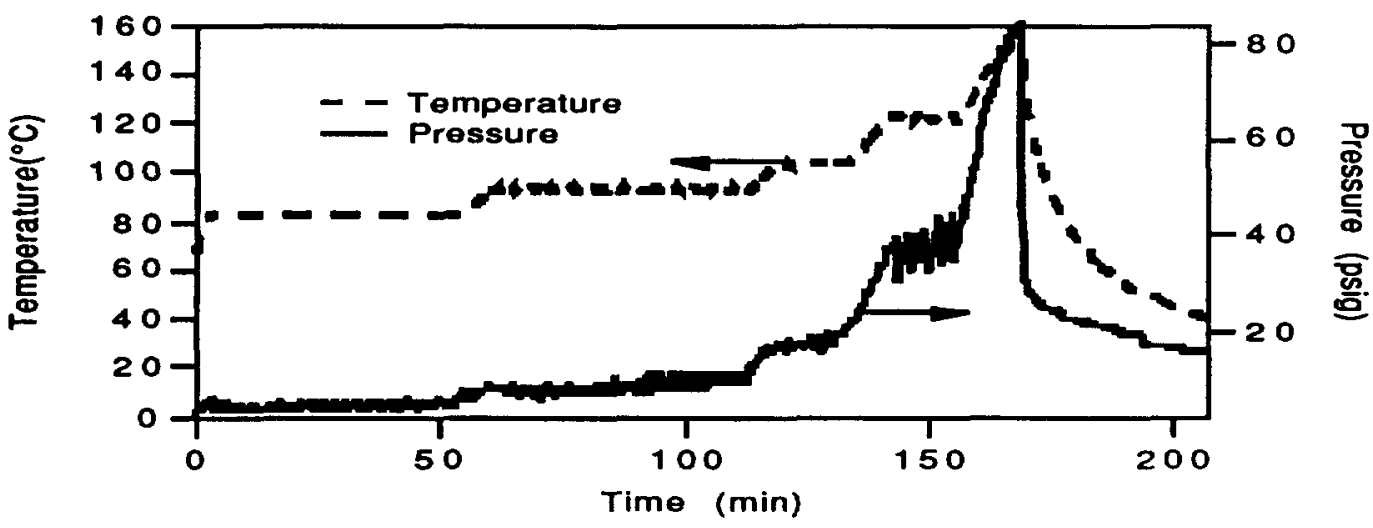

CSX -47

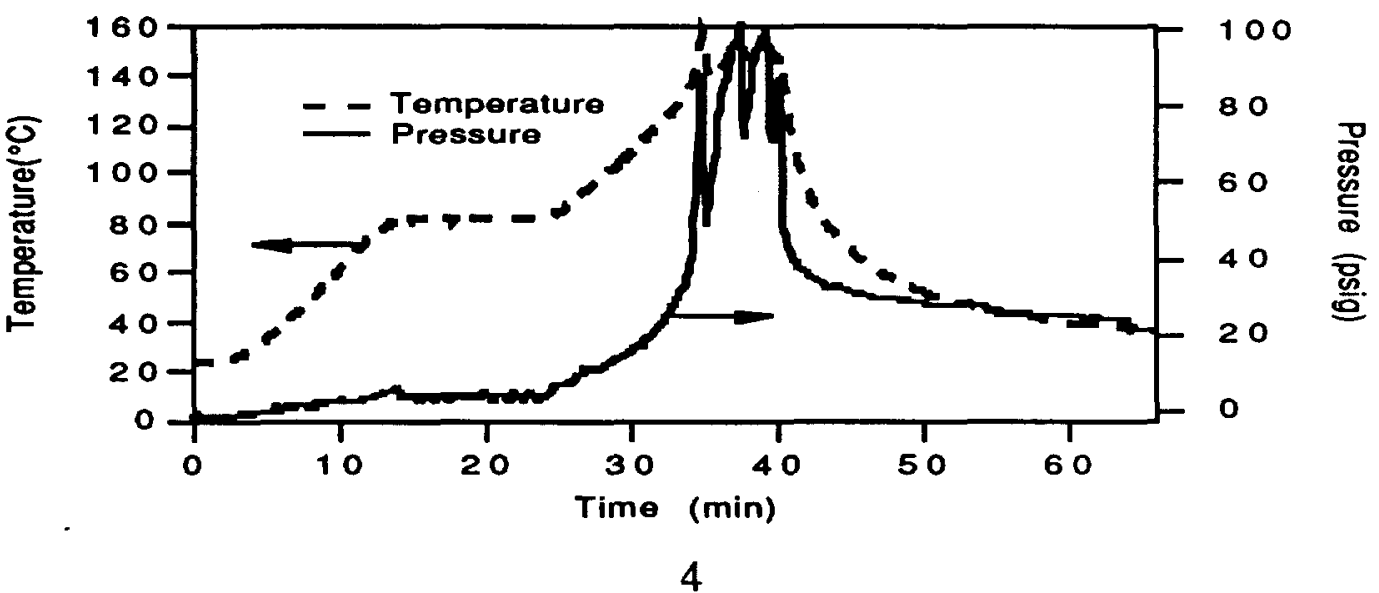


CSX-58

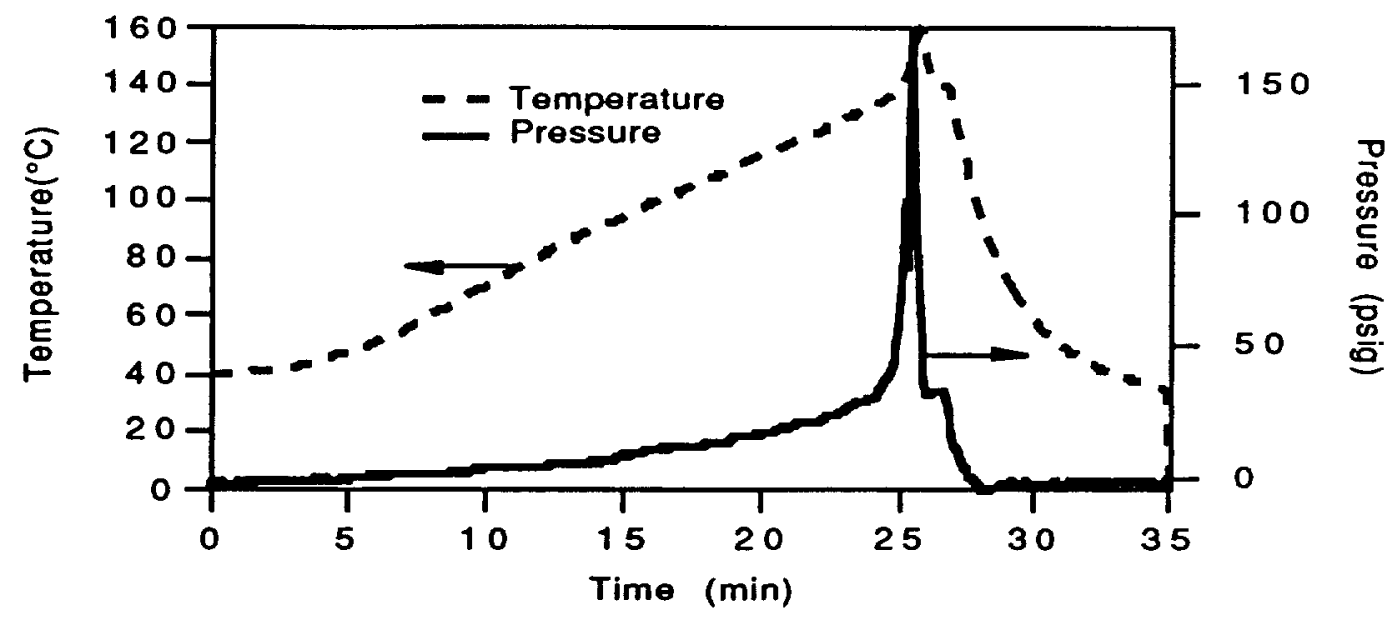

CSX-59

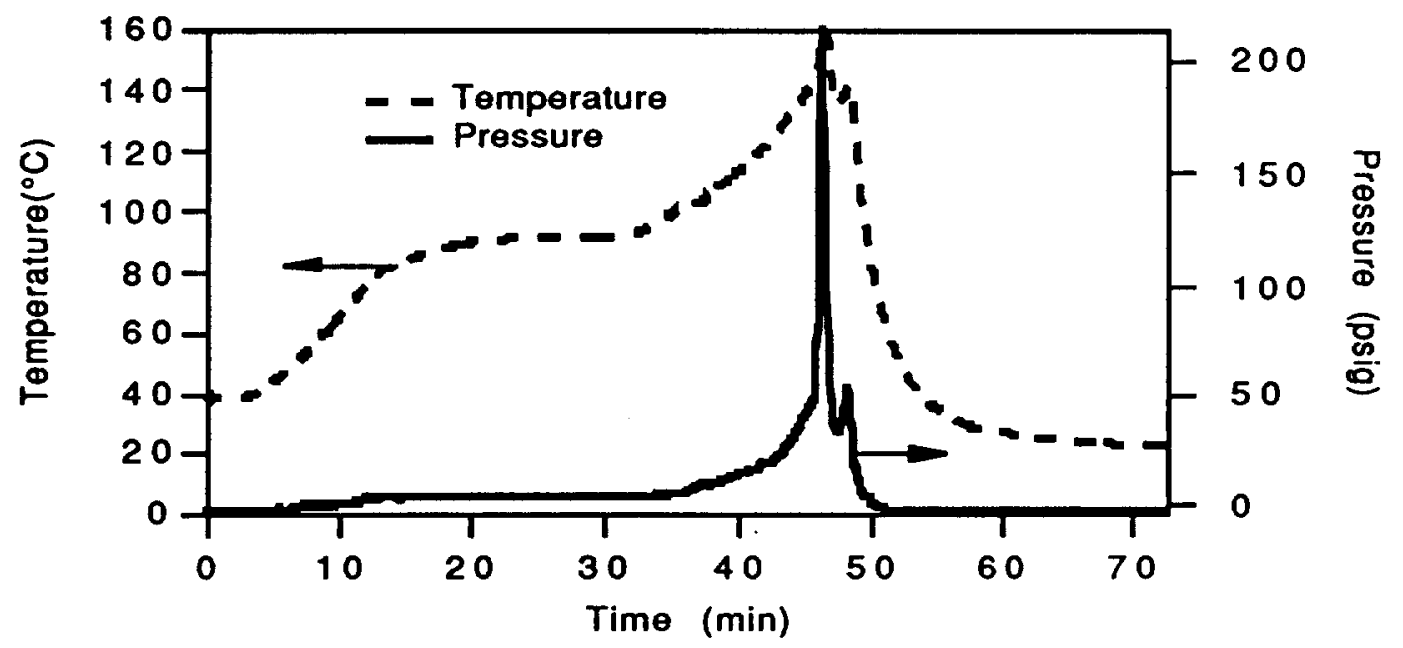

Gas Chromatograph Results for Octol Experiments (Air Free)

\begin{tabular}{|l|l|l|l|l|l|l|l|}
\hline Experiment & $\mathrm{CO}_{2}$ & $\mathrm{H}_{2}$ & $\mathrm{~N}_{2} \mathrm{O}$ & $\mathrm{N}_{2}$ & $\mathrm{CO}$ & $\mathrm{O}_{2}$ & Unknown \\
\hline $\mathrm{CSX}-46$ & Trace & & $94.8 \%$ & & $0.128 \%$ & & $5.07 \%$ \\
\hline $\mathrm{CSX}-47$ & & Trace & $90.9 \%$ & $6.86 \%$ & $0.122 \%$ & & $2.12 \%$ \\
\hline $\mathrm{CSX}-49$ & & & $\sim 100 \%$ & $0 \%$ & $0.38 \%$ & & $0 \%$ \\
\hline $\mathrm{CSX}-50$ & & & $\sim 100 \%$ & $0 \%$ & $0.28 \%$ & & $0 \%$ \\
\hline $\mathrm{CSX}-59$ & $0.182 \%$ & & $67.4 \%$ & $10.83 \%$ & $0.096 \%$ & $0.210 \%$ & $21.28 \%$ \\
\hline
\end{tabular}

CSX-58 did not have a GC run on it because of the release of some liquid out of the relief valve, and the presence of a partial vacuum in the reactor system.

Percent of starting nitrogen reacted, converted to $\mathrm{N}_{2} \mathrm{O}$ and $\mathrm{N}_{2}$

\begin{tabular}{|c|c|c|c|}
\hline Experiment\# & $\% \mathrm{~N}_{2} \mathrm{O}$ & $\% \mathrm{~N}_{2}$ & $\%$ Total \\
\hline CSX-46 & 31 & & 31 \\
\hline $\mathrm{CSX}-47$ & 52 & 0.13 & 52.13 \\
\hline
\end{tabular}


The stoichiometry used for octol is that 0.6 grams of $\mathrm{NaOH}$ is needed per gram of octol. The best results were when the reaction was directly heated to $150^{\circ} \mathrm{C}$. The only problem with this method is that an adequate relief valve must be present in order to handle the large quantity of gas released during the experiment. Roughly $110 \mathrm{~cm}^{3}$ (STP) of gas is produced for every gram of Octol. The average values of the gas components for the treatment of Octol with $\mathrm{NaOH}$ is $84.4 \% \mathrm{~N}_{2} \mathrm{O}, 5.90 \% \mathrm{~N}_{2}, 0.12 \% \mathrm{CO}$. All gas percentages are air free.

The TNT appears to melt and react at roughly $90^{\circ} \mathrm{C}$ allowing for the $\mathrm{HMX}$ to contact the base. This is the reason for the large jump in temperature and pressure during the reaction. Overall, octol is very suitable for base hydrolysis. The hydrolysate is a reddish-black liquid that does not lend itself to analysis by NMR. This might be due to the theory that the hydrolysate products of TNT are in a fine colloidal suspension, and not completely soluble with the base solution. Recent work by T. Spontarelli hopefully will solve this problem. Ammonia hydroxide was found to not be as effective as $\mathrm{NaOH}$, and tended to form insoluble salts with TNT. 


\section{Experimental Summary for Tritonal Experiments}

\begin{tabular}{|l|l|l|l|l|l|l|l|l}
\hline $\begin{array}{l}\text { Experiment } \\
\#\end{array}$ & $\begin{array}{l}\text { Mass of } \\
\text { Explosive }\end{array}$ & Description & $\begin{array}{l}\text { Concentration } \\
\text { of Base }\end{array}$ & $\begin{array}{l}\text { Volume } \\
\text { of Base }\end{array}$ & $\begin{array}{l}\text { Peak } \\
\text { Temp. }\end{array}$ & $\begin{array}{l}\text { Time at } \\
\text { Temp. }\end{array}$ & \% Reacted & Date \\
\hline CSX-54 & $50.154 \mathrm{~g}$ & 1 piece & $3 \mathrm{M} \mathrm{NaOH}$ & $250 \mathrm{~mL}$ & $>80^{\circ} \mathrm{C}$ & 33 minutes & $12.1^{* *}$ & $2 / 23 / 9$ \\
\hline $\mathrm{CSX}-55^{3}$ & $41.965 \mathrm{~g}$ & Flat Disk & $3 \mathrm{M} \mathrm{NaOH}$ & $500 \mathrm{~mL}$ & $95^{\circ} \mathrm{C}$ & 21 minutes & 68.8 & $2 / 23 / 9$ \\
\hline $\mathrm{CSX}-56^{*}$ & $51.27 \mathrm{~g}$ & 1 piece & $1.5 \mathrm{M} \mathrm{NaOH}$ & $750 \mathrm{~mL}$ & $95^{\circ} \mathrm{C}$ & 19 minutes & 83.5 & $2 / 24 / 9$ \\
\hline $\mathrm{CSX}-56-2^{3}$ & $20.234 \mathrm{~g}$ & scrap & $1.5 \mathrm{M} \mathrm{NaOH}$ & $400 \mathrm{~mL}$ & $95^{\circ} \mathrm{C}$ & 20 minutes & $14.9^{* * *}$ & $2 / 24 / 9$ \\
\hline $\mathrm{CSX}-57^{*}$ & $49.404 \mathrm{~g}$ & 1-piece & $1.5 \mathrm{M} \mathrm{NaOH}$ & $1000 \mathrm{~mL}$ & $95^{\circ} \mathrm{C}$ & 30 minutes & 99.5 & $2 / 26 / 9$ \\
\hline
\end{tabular}

* A solid disk formed on the bottom of reactor. Acetone was needed to remove the solid disk. Mass reacted was determined after acetone evaporated. No stirring was used in this experiments

** A solid disk formed, but was easily removed. This disk was used in CSX-55. No stirring was used in this experiment.

*** Liquid level was not sufficiently high enough for good mixing.

- Stirring was used.

\section{Temperature and Pressure Profiles for Tritonal Experiments}

\section{$\operatorname{CSX}-54$}

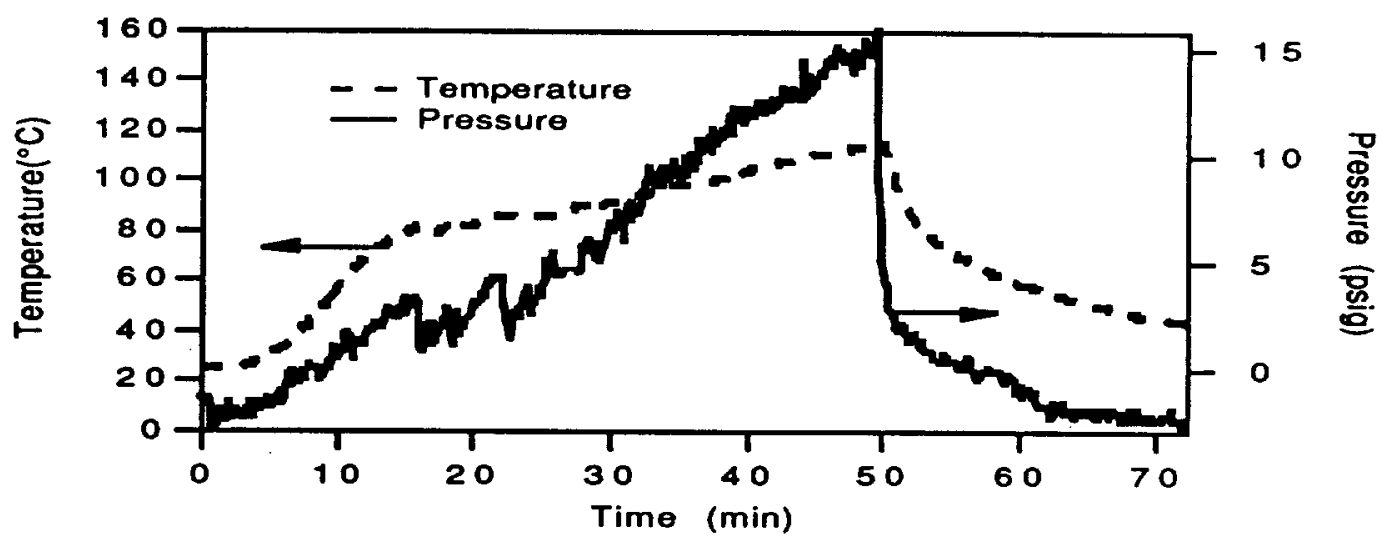

CSX-55 


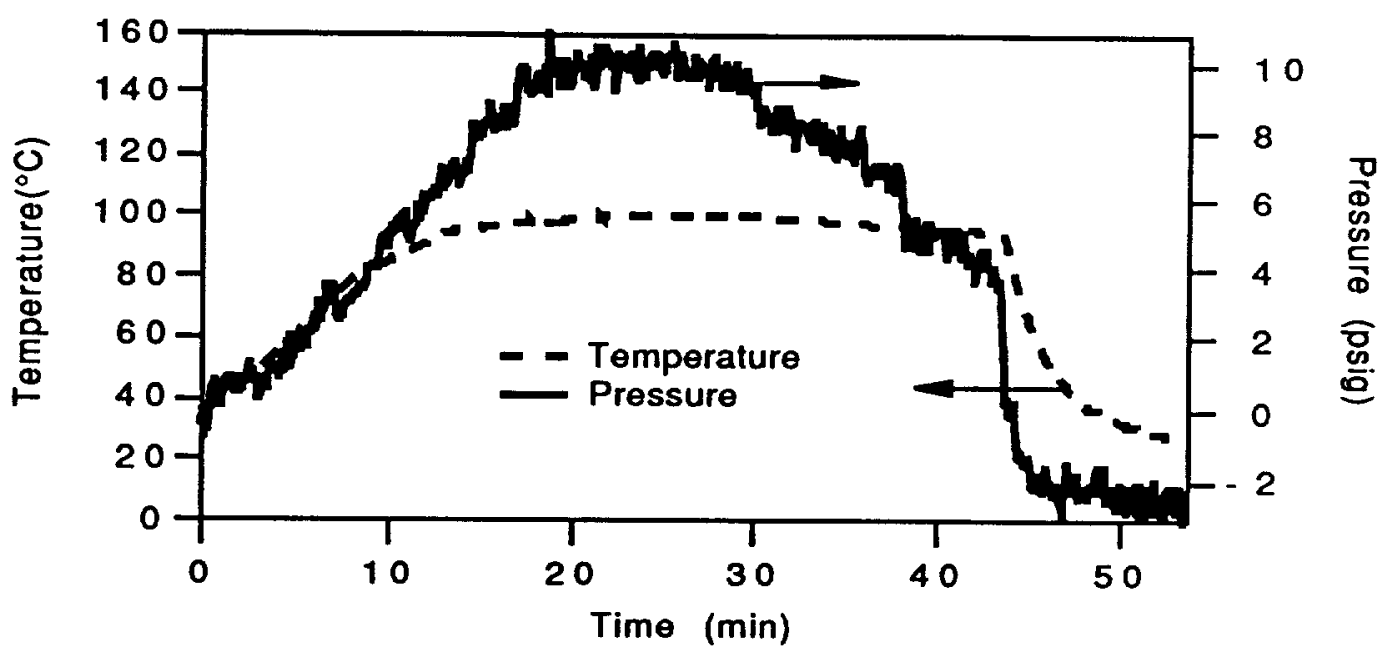

CSX-56

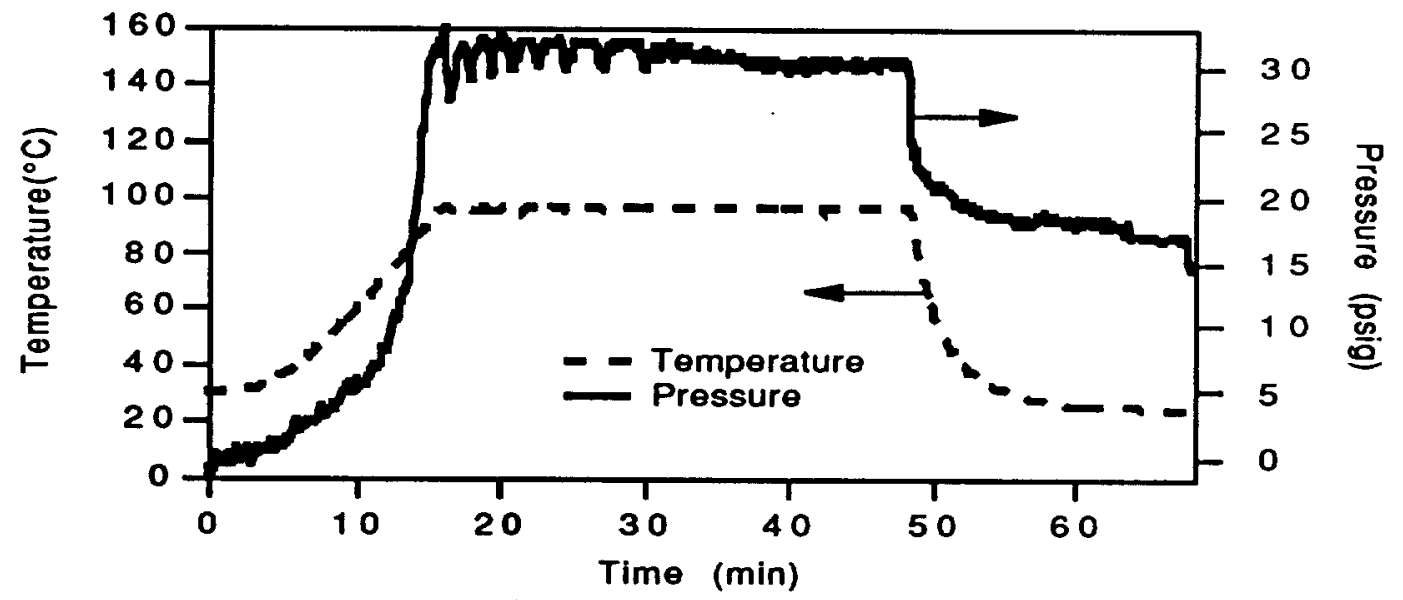

CSX-56-2

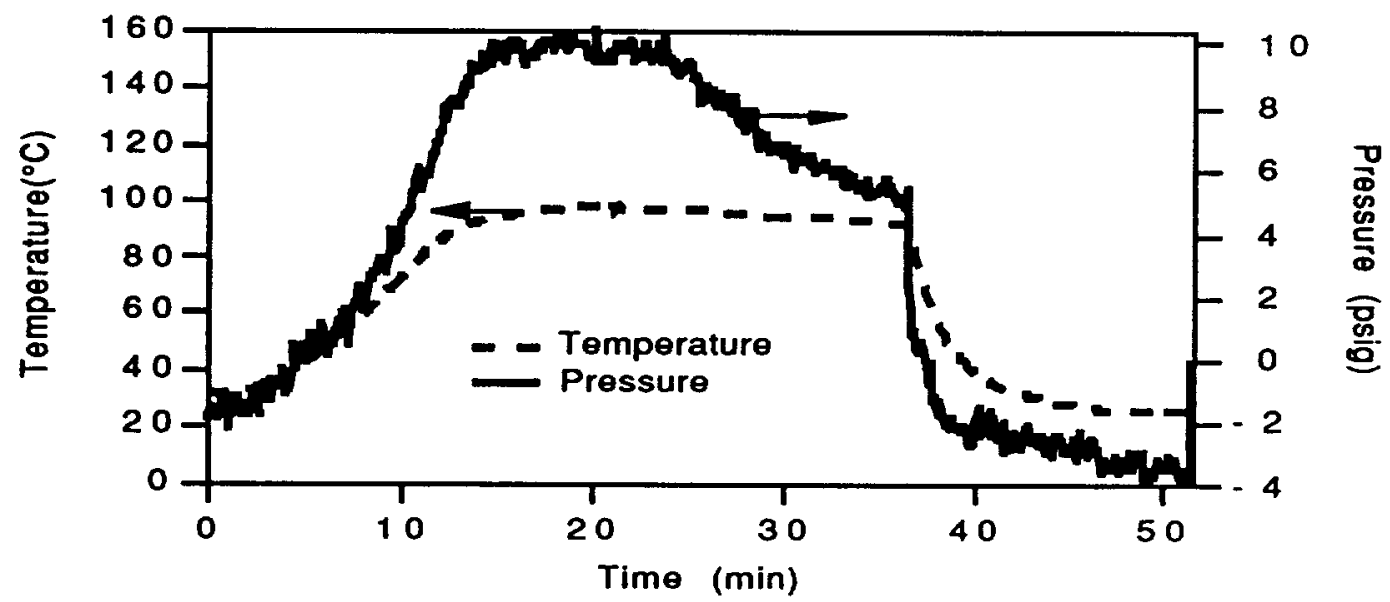

$\operatorname{CSX-57}$ 


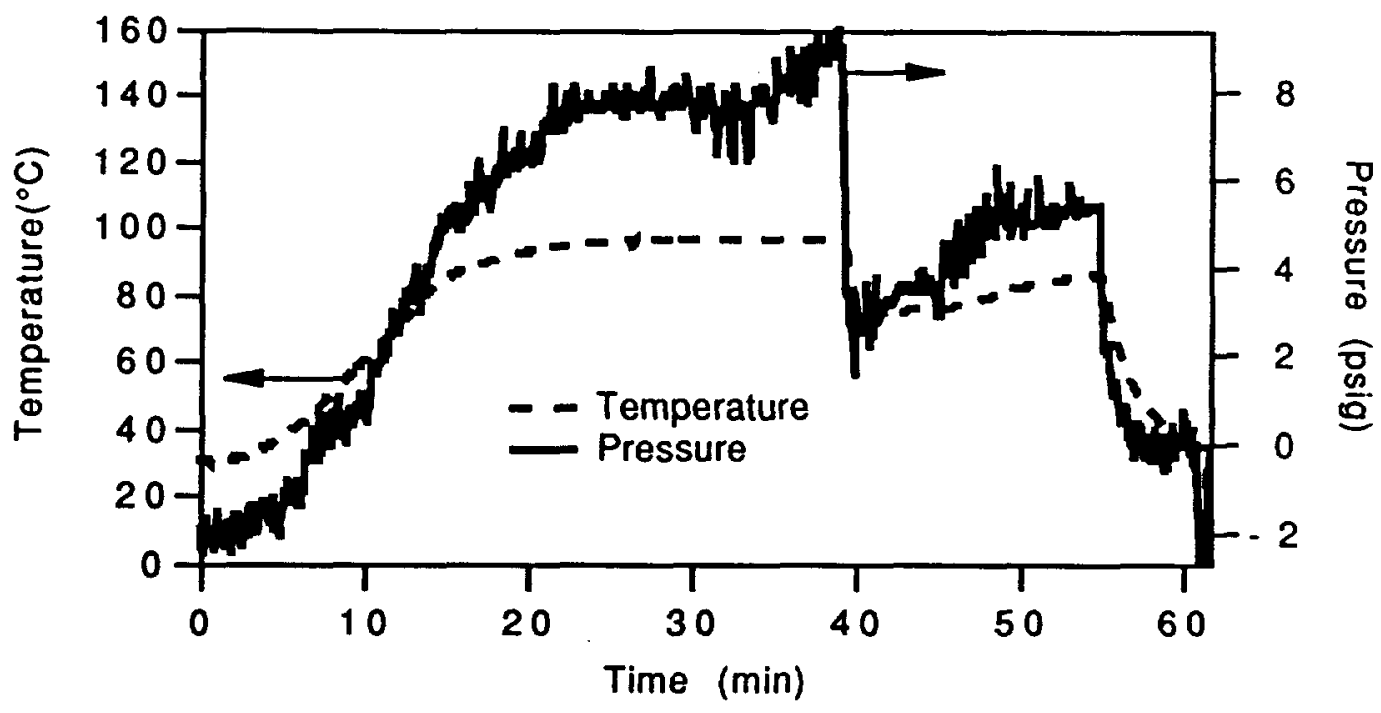

GC Results for Tritonal Experiments (Air Free)

\begin{tabular}{|l|l|l|l|l|l|l|l|}
\hline Experiment & $\mathrm{CO}_{2}$ & $\mathrm{H}_{2}$ & $\mathrm{~N}_{2} \mathrm{O}$ & $\mathrm{N}_{2}$ & $\mathrm{CO}$ & $\mathrm{O}_{2}$ & Unknown \\
\hline CSX-53 & & & $0.96 \%$ & $58.5 \%$ & $0.04 \%$ & & $40.5 \%$ \\
\hline CSX-56 & & $\sim 100 \%$ & & & $0.22 \%$ & & \\
\hline
\end{tabular}

The stoichiometry used for the reaction of tritonal with $\mathrm{NaOH}$ is that 1.2 grams of $\mathrm{NaOH}$ is needed for every gram of tritonal. The large difference in stoichiometry between tritonal and octol is due to the presence of aluminum, which consumed two moles of $\mathrm{NaOH}$ per mole of aluminum. The best results were when the solution was heated to $-95^{\circ} \mathrm{C}$. Good mixing is very important, if mixing is poor the TNT in the tritonal will melt and sit on the bottom of the reactor as a solid lump. When this happens, the mass transfer is poor enough, that the reaction does no proceed to any great degree. Very little gas is produced from the TNT, but in one run, a large amount of hydrogen gas was produced from its reaction with aluminum.

It appears that the large discrepancies between the off gas analysis of different runs of tritonal is due to the samples not being completely homogeneous. The hydrolysate is dark red in color, and does not lend itself to analysis by NMR for the same reason as octol (see note on T. spont on page 3). Overall tritonal is very ideal for base hydrolysis using $\mathrm{NaOH}$ and can be performed at fairly low temperatures. Ammonia was not found to be as effective as $\mathrm{NaOH}$, and tended to form insoluble salts with TNT. 


\section{Effectiveness of base hydrolysis on PBXN-109}

PBXN-109 is one of the two explosives that contains HTPBD as a binder. Due to the resistance that the binder has to base, DMSO will be used to hopefully swell the binder, and allow access to the RDX. One problem that has come up is that the DMSO does not easily become separated from the binder after the experiment. This makes it difficult to determine the weight of the explosive after the reaction is complete. The temperature and pressure curves for the DMSO experiments are listed below the table.

20\% DMSO Experimental Summary

\begin{tabular}{|c|c|c|c|c|c|c|c|c|}
\hline $\begin{array}{l}\text { Experiment } \\
\#\end{array}$ & $\begin{array}{l}\text { Mass of } \\
\text { Explosive }\end{array}$ & Description & $\begin{array}{l}\text { Concentration } \\
\text { of Base }\end{array}$ & $\begin{array}{l}\text { Volume } \\
\text { of Base }\end{array}$ & $\begin{array}{l}\text { Peak } \\
\text { Temp. }\end{array}$ & $\begin{array}{l}\text { Time at } \\
\text { Temp. }\end{array}$ & \% Reacted & Date \\
\hline $\operatorname{cSX}-60^{\circ}$ & $51.958 \mathrm{~g}$ & 1 piece & $3 \mathrm{M} \mathrm{NaOH}$ & $500 \mathrm{~mL}$ & $150^{\circ} \mathrm{C}$ & lhr & -4.5 & $2 / 28 / 96$ \\
\hline $\operatorname{CSX}-61^{\circ}$ & $51.585 \mathrm{~g}$ & 1 piece & $3 \mathrm{M} \mathrm{NaOH}$ & $500 \mathrm{~mL}$ & $150^{\circ} \mathrm{C}$ & $1 \mathrm{hr}$ & -5.9 & $2 / 29 / 96$ \\
\hline $\operatorname{csX}-62^{2}$ & $51.49 \mathrm{~g}$ & 1 piece & $3 \mathrm{M} \mathrm{NaOH}$ & $500 \mathrm{~mL}$ & $150^{\circ} \mathrm{C}$ & $3 \mathrm{hr}$ & & $2 / 29 / 96$ \\
\hline \multicolumn{9}{|c|}{$50 \%$ DMSO experiment } \\
\hline $\begin{array}{l}\text { Experiment } \\
\#\end{array}$ & $\begin{array}{l}\text { Mass of } \\
\text { Explosive }\end{array}$ & Description & $\begin{array}{l}\text { Concentration } \\
\text { of Base }\end{array}$ & $\begin{array}{l}\text { Volume } \\
\text { of Base }\end{array}$ & $\begin{array}{l}\text { Peak } \\
\text { Temp. }\end{array}$ & $\begin{array}{l}\text { Time at } \\
\text { Temp. }\end{array}$ & $\%$ Reacted & Date \\
\hline $\operatorname{CSX}-63^{\prime \prime}$ & $51.557 \mathrm{~g}$ & 1 piece & $3 \mathrm{M} \mathrm{NaOH}$ & $500 \mathrm{~mL}$ & $150^{\circ} \mathrm{C}$ & $4 \mathrm{hr}$ & $-<38.3$ & $3 / 1 / 96$ \\
\hline \multicolumn{9}{|c|}{$46 \%$ DMSO Experiment } \\
\hline $\begin{array}{l}\text { Experiment } \\
\#\end{array}$ & $\begin{array}{l}\text { Mass of } \\
\text { Explosive }\end{array}$ & Description & $\begin{array}{l}\text { Concentration } \\
\text { of Base }\end{array}$ & $\begin{array}{l}\text { Volume } \\
\text { of Base }\end{array}$ & $\begin{array}{l}\text { Peak } \\
\text { Temp. }\end{array}$ & $\begin{array}{l}\text { Time at } \\
\text { Temp. }\end{array}$ & $\begin{array}{l}\% \\
\text { Reacted }\end{array}$ & Date \\
\hline CSX-64" & 51.606 & 1 piece & $3 \mathrm{M} \mathrm{NaOH}$ & $500 \mathrm{~mL}$ & $150^{\circ} \mathrm{C}$ & $6 \mathrm{hr}$ & $\sim 34.6$ & $3 / 2 / 96$ \\
\hline
\end{tabular}

'Stirring was used

Temperature and Pressure Plots for the PBXN-109 Experiments

CSX-60

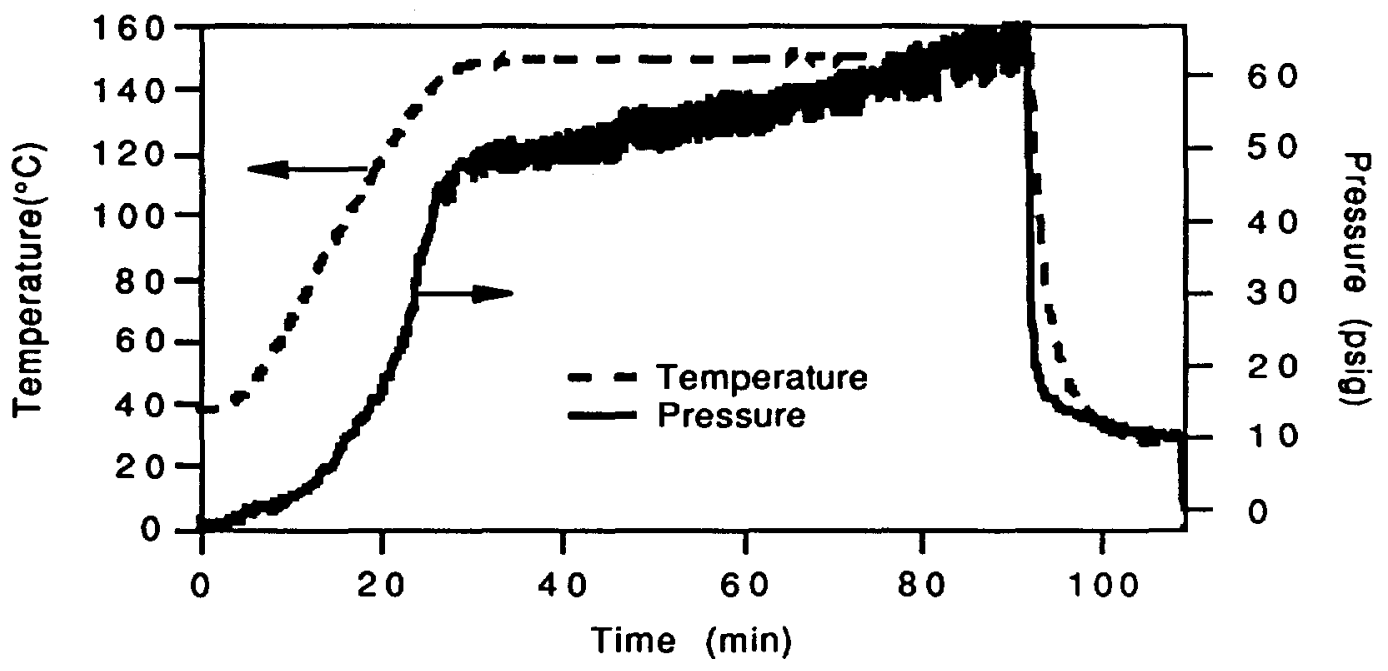


CSX-61

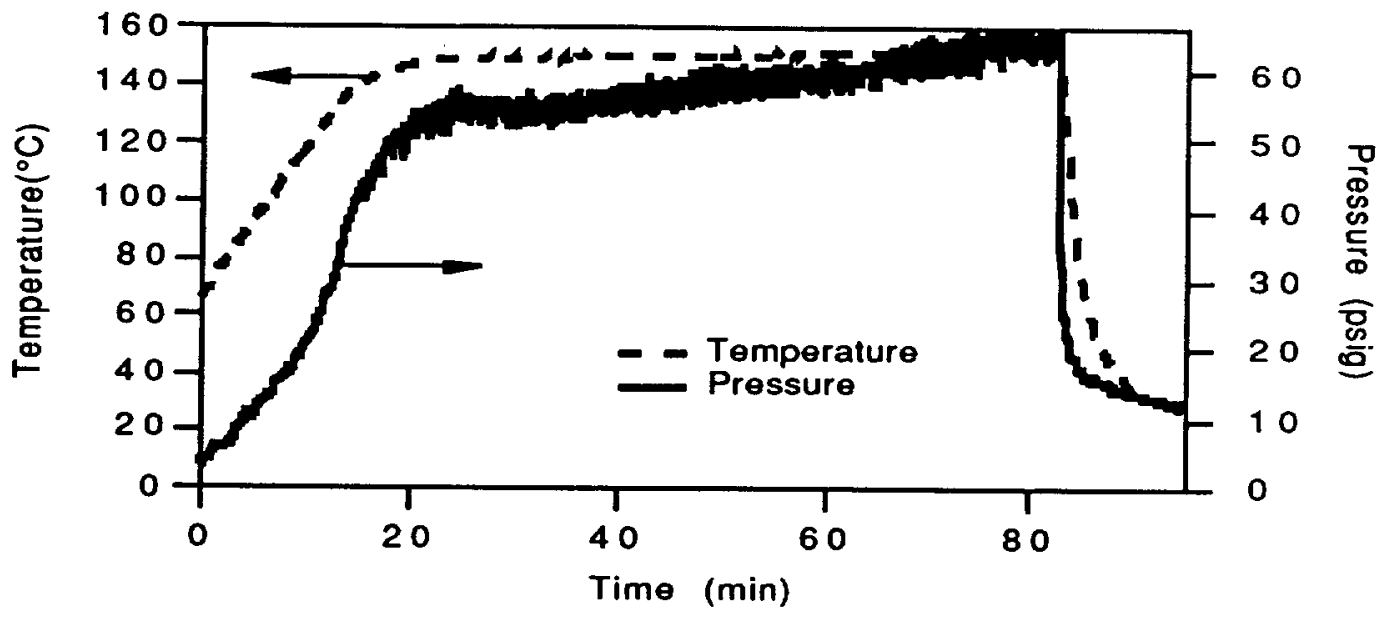

CSX-62

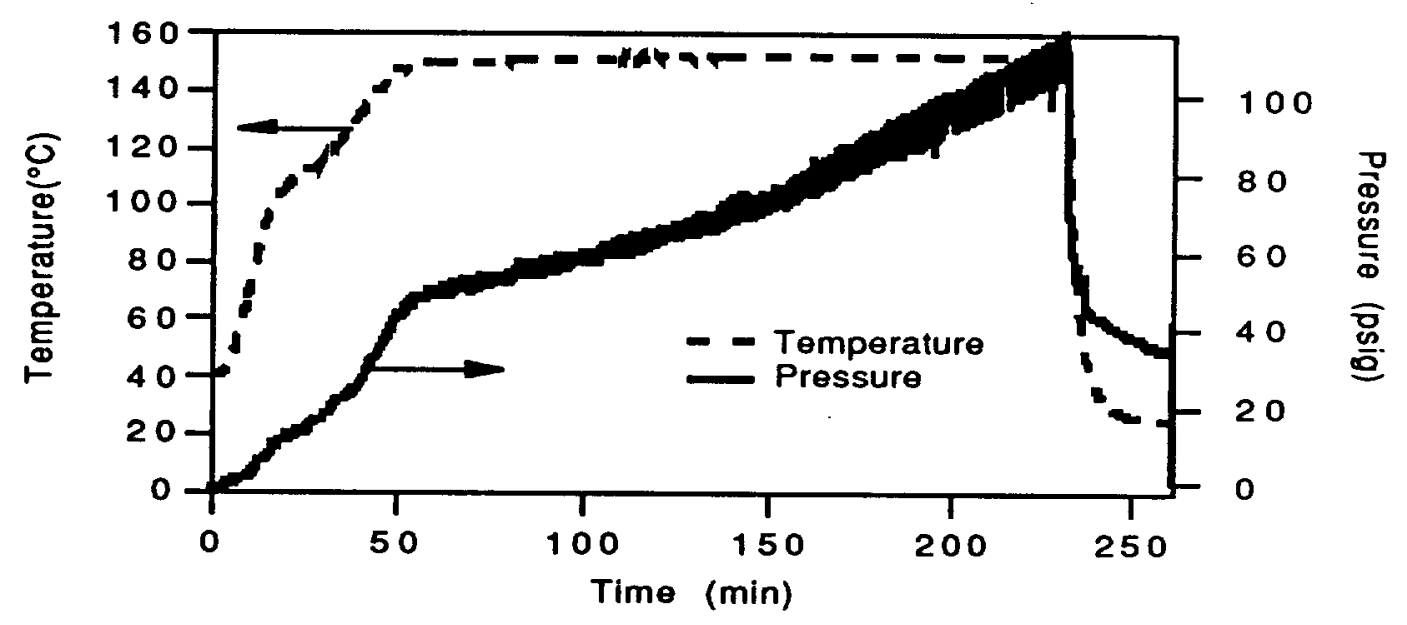

CSX-63

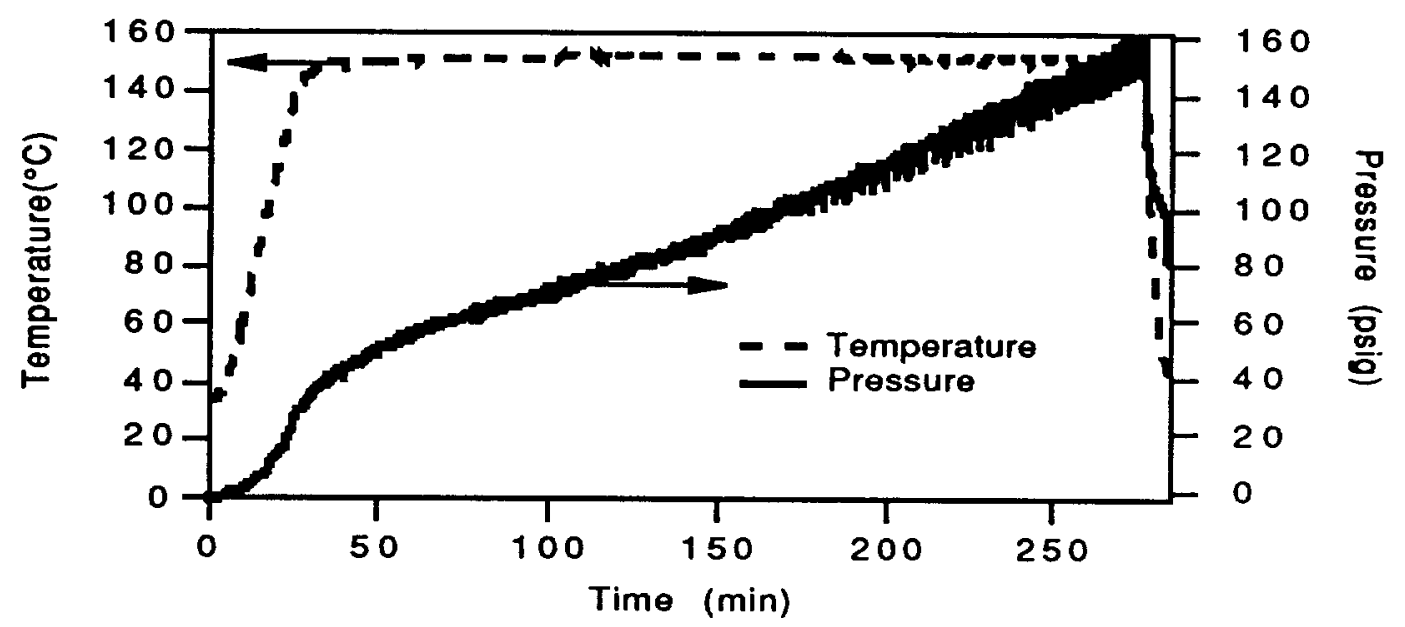




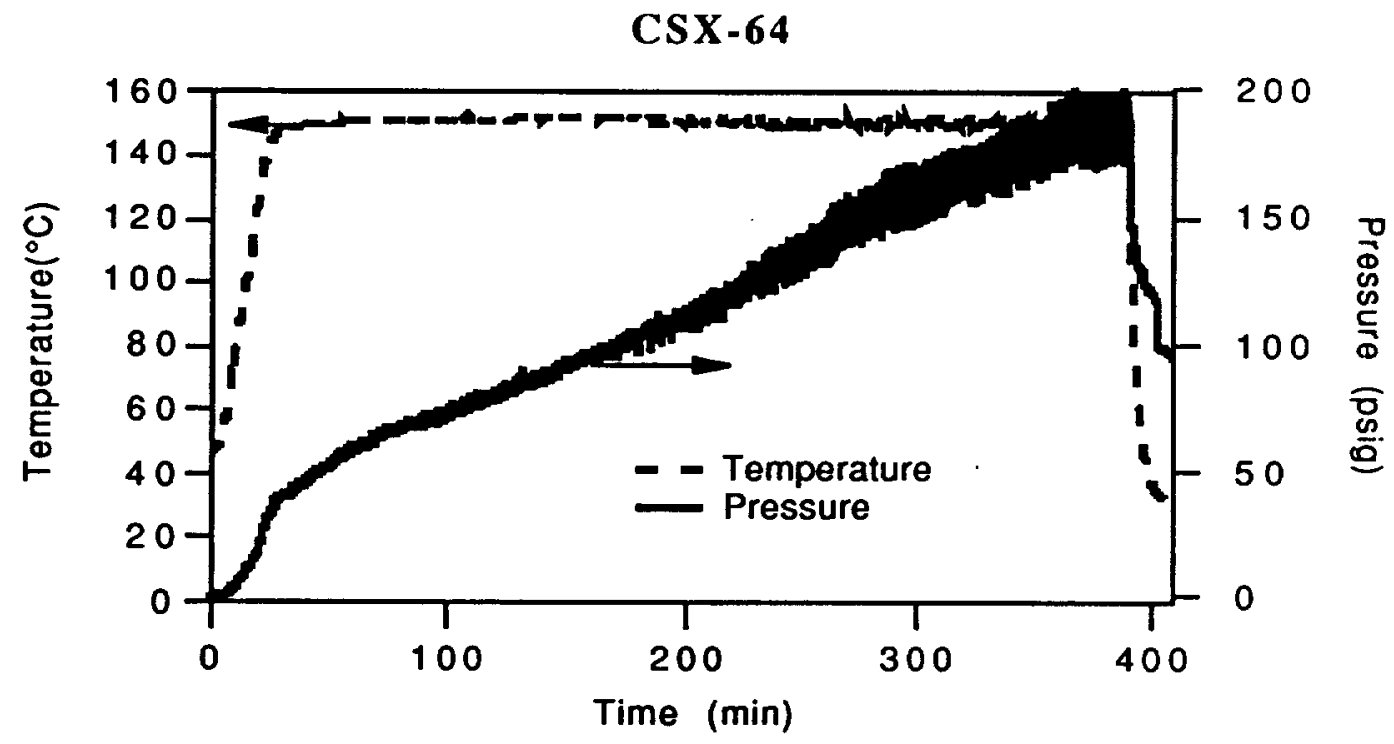

GC Results for PBXN-109 (Air Free)

\begin{tabular}{|l|l|l|l|l|l|l|l|}
\hline Experiment & $\mathrm{CO}_{2}$ & $\mathrm{H}_{2}$ & $\mathrm{~N}_{2} \mathrm{O}$ & $\mathrm{N}_{2}$ & $\mathrm{CO}$ & $\mathrm{O}_{2}$ & Unknown \\
\hline $\mathrm{CSX}-60$ & & $-61.1 \%$ & $38.9 \%$ & & & & \\
\hline $\mathrm{CSX}-61$ & & $-61.3 \%$ & $35.0 \%$ & $2.69 \%$ & & & \\
\hline $\mathrm{CSX}-62$ & & $-49.0 \%$ & $34.1 \%$ & $12.5 \%$ & $0.088 \%$ & & $4.31 \%$ \\
\hline $\mathrm{CSX}-63$ & & $-52.2 \%$ & $5.84 \%$ & $38.0 \%$ & $0.078 \%$ & & $3.88 \%$ \\
\hline $\mathrm{CSX}-64$ & & $-54.8 \%$ & $2.86 \%$ & $38.9 \%$ & $0.079 \%$ & & $3.36 \%$ \\
\hline
\end{tabular}

The stoichiometry used for these experiment was 0.6 grams of $\mathrm{NaOH}$ per gram of PBXN-109. As the reaction proceeded, so did the percentage of hydrogen gas. Carbon monoxide and nitrogen gas stayed fairly constant, while the percentage of $\mathrm{N}_{2} \mathrm{O}$ dropped. The sold left after CSX-64 was split into pieces had a very definable band between the reacted and the unreacted $\mathrm{RDX}$ was present. It appears that the reaction penetrated the solid only $\sim 1 / 8$ " on each side, after six hours. PBXN-109 is a very difficult explosive to process, and pre-treatment will most likely be needed. The explosives could be sliced into smaller pieces to help to alleviate some of the mass transfer problems. A different solvent could also be used, but it is difficult to find one that works well with hot base, and it not a disposal problem. PBXN-109 might not be well suited for base hydrolysis. For a two inch piece, estimate between 50 and 70 hours for complete destruction of the RDX and aluminum. Neither ammonia hydroxide or sodium carbonate has been tried at this time. 


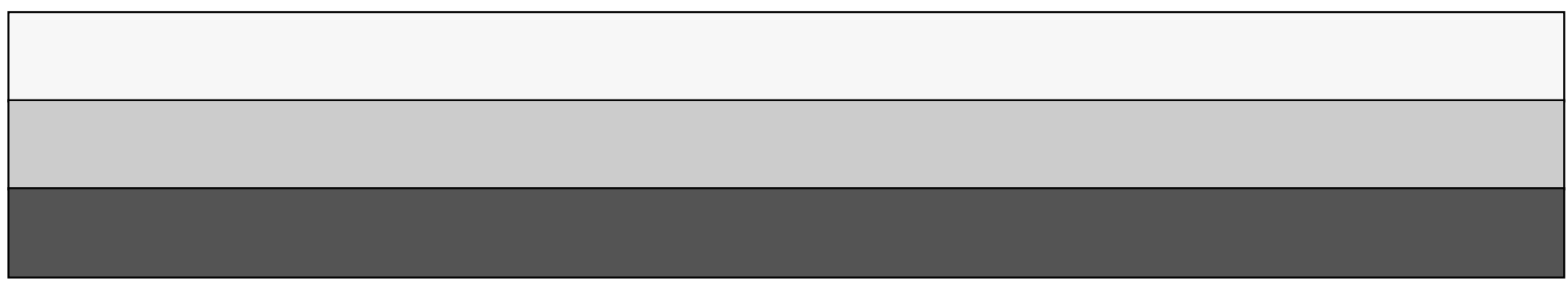

